\title{
BUILDING ON EUROPEAN SCIENTIFIC EXCELLENCE TO DEVELOP AN EDUCATIONAL PROGRAM ON INTERMODAL CONNECTIONS FOR LATVIA AND THE REGION
}

\author{
Lambros Mitropoulos ${ }^{1}$, Giannis Adamos ${ }^{2}$, Eftihia Nathanail ${ }^{3}$, \\ Irina Yatskiv (Jackiva) ${ }^{4}$, Igor Kabashkin ${ }^{5}$ \\ ${ }^{1,2,3}$ Dept of Civil Engineering, University of Thessaly, Volos, Greece \\ $4,{ }^{5}$ Dept of Mathematical Methods and Modelling, \\ Transport and Telecommunication Institute, Riga, Latvia
}

Submitted 22 November 2016; accepted 21 December 2016

\begin{abstract}
Economic and social factors, including existing trends in urban population and employment growth combined with urbanization, have led to enhanced consumption and thus, increasing freight flows in the cities. Mitigation of transport impacts has led to plans towards a more sustainable urban environment. However, managerial and regulatory barriers restrict the incorporation of technological instruments and solutions to the sustainable dimension of decision-making and planning. This paper has sought to bridge this gap by organizing an educational and training program, which involves the participation of todays and tomorrow's researchers, decision-makers and practitioners. Towards this direction, a methodology is developed that identifies existing gaps between the transport industry and the existing research, education and training programs and converts identified requirements and gaps into training courses. The paper addresses the context of intermodal interconnections for the case of Latvia and the region for stimulating and strengthening its scientific and technological capacity by providing knowledge in the field of smart interconnecting sustainable transport networks. The 2-level gap analysis that was developed and implemented with respect to the thematic areas of (1) 'Governance and policy development', (2) 'Smart solutions', and (3) 'Decision-making', and the validation process that followed, has revealed several requirements that exist currently for passenger and freight interchanges and educational programs for Latvia and the region. Based on the identified educational requirements for Latvia and the region, 20 educational areas were created that resulted in 12 courses for passenger and freight transport interchanges that are going to be used for training and education in Latvia.
\end{abstract}

Keywords: interconnecting networks; interchanges; education; training programs; gap analysis, transportation.

\section{Introduction}

Urban implications of mobility have been of concern to the European Parliament, the Council, the European Economic and Social Committee and the Committee of the Regions (EC 2009). In this context, urbanisation, and its impacts on transport, is identified as one of the key challenges in providing a more sustainable transport system, through short and medium-term actions that integrate urban mobility and promote partnerships at a local, regional and national level. At a glance, statistics show that (Grimm et al. 2008; EC 2014; Figliozzi 2010; Russo, Comi 2012):

- more than 100 million people have mitigated to cities globally since the beginning of this decade; - over $50 \%$ of the world population lives in cities;

- approximately $75 \%$ of the population lives in urban areas in Europe;

- urban freight vehicles account for 6-18\% of total urban travel;

- urban freight transport accounts for $19 \%$ of energy use and $21 \%$ of $\mathrm{CO}_{2}$ emissions.

Additionally, freight transport present great challenges in urban areas, in terms of goods distribution and service allocation performance, and environmental impacts (air emission, traffic congestion, road safety, accidents and noise). Economic and social factors, such as existing trends in urban population and employment

Corresponding author: Lambros Mitropoulos

E-mail: lmit@civ.uth.gr

A preliminary version of this paper was presented at the 96th TRB (Transportation Research Board) Annual Meeting on 8-12 January 2017 (Washington, DC, US). Paper No. 17-04809-

Developing an Educational Program for Transportation across Regions: the Case for Intermodal Connections for Latvia and the Region 
growth combined with urbanization, have led to enhanced consumption and thus, increasing freight flows in the cities. In order to mitigate the impacts of these trends, the European Commission has set a range of goals towards shifting to a more sustainable urban environment.

It becomes necessary for cities and stakeholders to identify new strategies to improve quality of life of citizens and to set up urban planning according to economic competitiveness and business needs, but also to emerging travelling and consuming trends. However, a contradictory situation is met in decision-making and planning, where, even if there is a variety of new technological instruments and solutions, still, economic, managerial and regulatory barriers restrict the coherent incorporation of these instruments and solutions to the sustainable dimension of the overall management.

Understanding of the aforementioned impacts and trends requires targeted actions that aim at organizing an educational and training program, which involves the participation of todays and tomorrow's researchers, decision-makers and practitioners. This will generate sustainable collaborations as well as efficient and appropriate interactions between research and practice with view to stimulate changes of the current organizational and behavioural patterns. Towards this direction, the aim of this paper is the development of a methodology that identifies existing gaps between the transport industry and the research, education and training programs and converts potential requirements into training courses.

The methodology is applied for the case of Latvia and the region, for stimulating and strengthening its scientific and technological capacity by providing knowledge in the field of smart interconnecting sustainable transport networks. The case of Latvia is selected to correspond to the national priority of Latvia 'Growth of the national economy' by strengthening research and facilitating knowledge transfer between higher education, science and the private sector. The analysis focuses on in-depth investigation of the current situation and trends that exist in Latvia and the region, about the planning and operation of intermodal terminals. These trends are then compared to the current state of good practices of intermodal terminals and the smart solutions at European Union level. In parallel, an in-depth analysis of existing educational programs in Latvia and the region is conducted.

\section{Methodological Approach}

The aim of the proposed methodology in this study is the development of an educational program in transport that it explicitly addresses the needs and gaps that might exist at regional level. Thomas et al. (2015) developed a six-step approach for the development of curriculum for medical programs:

- problem identification;

- general needs assessment;

- goals and objectives;

- educational strategies;
- implementation;

- evaluation and feedback.

El Sawi (1996) proposed six important considerations for the development of a curriculum:

- identification of an issue or need;

- identification of characteristics and needs of learners;

- intended outcomes;

- relevant content;

- methods to accomplish outcomes;

- evaluation strategies.

The educational program on intermodal connections that is developed in this paper has the potential to be applied at any eligible European Union region. The basic methodological steps that are explicitly presented in this section can be applied at any level of spatial analysis (e.g., continent or country). Towards this direction, the methodology focuses on the identification of the existing status for and gaps between (1) the transport industry, and (2) the research, education and training programs, at both European Union and the eligible region. Eligible region here is defined the country that is interested in developing a transport program in interconnecting transport networks. Identified gaps are anticipated to constitute the basis for the formulation of an educational program in transport, to fill in the revealed gaps. The methodological steps that are developed to support the development of an education program in transport are shown in Figure:

- Step 1. Data collection and analysis for (1) the state of practice in interconnecting transport networks in the eligible region, and (2) research, educational and training programs in the eligible region.

- Step 2. Data collection and analysis for (1) the state of art in interconnecting transport networks in Europe, and (2) research, educational and training programs in European Union.

- Step 3. Assessment of present situation by comparing the state of art in European Union and the state of practice in the eligible region in terms of interconnecting transport networks. The first level gap analysis outlined the features and differences between the eligible region and European Union (Gap analysis 1).

- Step 4. Step 3 results are assessed against current research, educational and training programs. The second level gap analysis outlines the educational deficiencies in the eligible region as compared to the requirements of the domain of transport network interconnections (Gap analysis 2).

- Step 5. The planned development of the eligible region's transport networks interconnections are described to define the trends in the region regarding the planning and operation of intermodal terminals.

- Step 6. Based on the two-level gap analyses and outputs from Step 5, the knowledge requirements for intermodal terminal development for the eligible region are identified. 


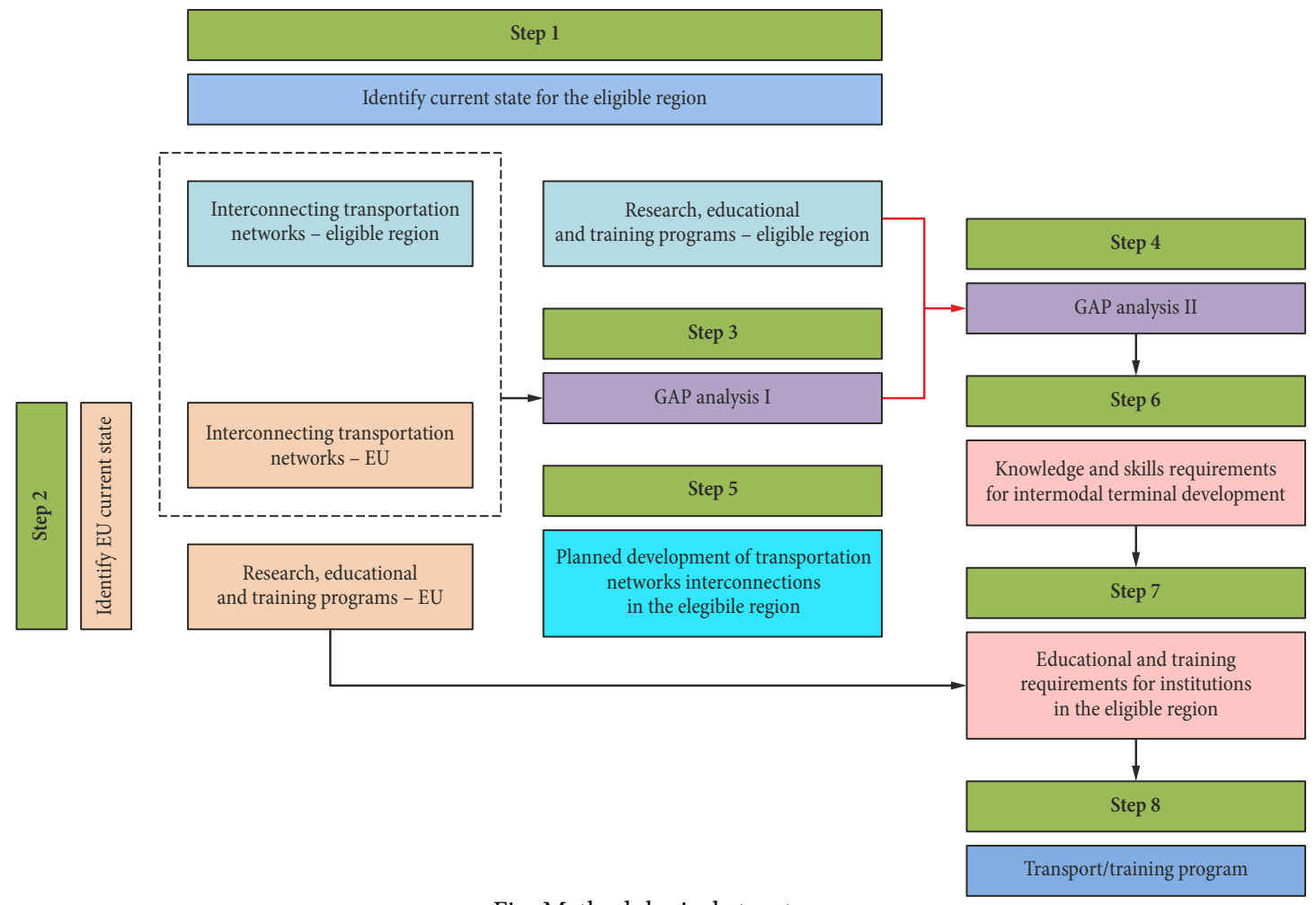

Fig. Methodological structure

(source: modified from Nathanail et al. (2016))

- Step 7. Step 6 results and knowledge of educational programs in the European Union (Step 2) are used as input towards validating the educational and training requirements for the regional institutions.

- Step 8. Formulation of a plan of action to bridge identified gaps and development of an educational program that addresses identified deficiencies/requirements. The methodological approach adopted in the context of Step 8 comprises of two parts, as follows:

A. Identification of educational areas. Based on the identified educational requirements for the eligible region (i.e., the outcome of the twolevel gap analysis), the educational areas are identified.

B. Conversion to courses. The educational areas that are identified in Part A are combined based on their content (where applicable) to shape courses for the educational program in transport.

\section{Data Collection}

The following sections present the implementation of the methodological steps for Latvia and the surrounding regions. Each step of the methodology used different methods to collect the required information as follows:

1. Identification of research and thematic areas. Two areas of research are identified as of high relevance to the development of the educational program within the context of intermodal interconnections: (1) interconnecting transport networks, and (2) research, educa- tional and training programs. For each of the two areas, research is conducted for current practices in European Union on one hand, and Latvia and the region, on the other. In addition, and in order to investigate interchanges under the perspective of all potential involved stakeholders, three thematic areas were determined, namely:

- governance and policy development, which covers issues related to the interconnection of transport with land use planning, legislative, institutional and organizational frameworks;

- smart solutions, which exploit technological advancements and other innovative measures and tools, and enable the efficient operation of intermodal terminals, high quality services, environmental and energy protection, and sustainability;

- decision-making, which addresses impact assessment techniques and evaluation methods, as well as development of sustainable business and organizational models for collaborative schemes amongst the stakeholders.

2. Identification of data sources. The data sources that are used to collect the necessary information and data include:

- for the area 'Interconnecting transport networks': (1) European Union policy on intermodality, (2) extensive desk review on European Union research projects on interchanges (CORDIS 2016), (3) Data on the current state of the interchanges in Latvia and the region, and (4) strategic planning for Latvia (National Development Plan of Latvia for 2014-2020, see CCSC (2012)); 
- for the area 'Research, educational and training programs': (1) graduate educational programs relevant to transport in European institutions, and (2) educational programs for all levels relevant to transport in Latvia and the region; the latter have been based on online information, institute prospectus and personal communication.

3. Selection of good practices or indicative cases. Based on information accessibility and availability, and predefined selected criteria, this part led to the selection of good practices or indicative cases in each of the two areas of research: 'Interconnecting transport networks' and 'Research, educational and training programs'.

4. Tool development for data collection. For facilitating the data collection activities, two templates were developed, one for each research area, and used for both Latvia and the region and the European Union. Each template comprised a series of standardized questions, some of which with multiple-parts, allowing, also, for multiple-responses.

\section{Interconnecting Transport Networks}

The paper addresses the context of intermodal interconnections, thus interchanges for passenger mobility and freight transport by taking into account (1) the legal and organizational issues, (2) the relevant gender mobility gender needs and patterns of transport utilization, and
(3) the interaction with other domains, such as spatial planning and economic development. Transport interchanges are considered as the network components that enable intermodal operations. An extended review in passenger and freight interchanges in Europe and Latvia and the region is performed to reveal good practices. In physical terms, transport interchanges compose the field of intermodal activities, including the transferring from a long to a short distance network, from interurban transport to urban distribution, referred to as 'last mile' and the change of transport modes and/or vehicles (Nathanail et al. 2016).

\subsection{Passenger Interchanges}

In total, 41 passenger interchanges were reviewed, covering a wide range of the European Union, including 17 countries: France, Norway, Greece, Lithuania, Spain, United Kingdom, Finland, Hungary, Czech Republic, Netherlands, Germany, Switzerland, Austria, Denmark, Estonia, Belgium and Portugal. The $32 \%$ of the interchanges were identified as national hubs, and the rest $68 \%$ of the interchanges are considered as either National City terminals or other city/local terminals as shown in Table 1. Additionally, five more existing passenger interchanges, located in Latvia and the region were chosen as good practices corresponding to the defined thematic areas of this study; the specific interchanges were chosen in order to cover all three types of interchanges (Table 2).

Table 1. Overview of passenger interchanges in European Union

\begin{tabular}{|c|c|c|c|c|}
\hline \multirow[b]{2}{*}{ Interchange name } & \multirow[b]{2}{*}{ Country } & \multicolumn{3}{|c|}{ Interchange type } \\
\hline & & $\begin{array}{c}\text { National } \\
\text { hub }\end{array}$ & $\begin{array}{l}\text { National city } \\
\text { terminal }\end{array}$ & $\begin{array}{l}\text { Other city or local } \\
\text { terminals }\end{array}$ \\
\hline Vienna international airport & Austria & $x$ & & \\
\hline Linz central station & Austria & & $x$ & $x$ \\
\hline Brussels airport & Belgium & $\times$ & & \\
\hline Antwerp central station & Belgium & & $x$ & $x$ \\
\hline Liege Guillemins train station & Belgium & & $x$ & $x$ \\
\hline Brussels South & Belgium & & $\times$ & $\times$ \\
\hline Praha Ruzyně international airport & Czech Republic & $\times$ & & \\
\hline Prague terminus Dejvicka & Czech Republic & & $x$ & $\times$ \\
\hline Copenhagen airport & Denmark & $\times$ & & \\
\hline Port of Tallinn & Estonia & $\times$ & & \\
\hline Kamppi terminal & Finland & & $x$ & $x$ \\
\hline Armentiéres station & France & & $\times$ & $\times$ \\
\hline Gare Lille Frandres-Europe & France & & $x$ & $\times$ \\
\hline Charles de Gaulle airport & France & $\times$ & & \\
\hline Port of Calais & France & $x$ & & \\
\hline Frankfurt airport & Germany & $x$ & & \\
\hline Berlin central station & Germany & & $x$ & $x$ \\
\hline Karlsruhe central station & Germany & & $x$ & $x$ \\
\hline Thessaloniki port & Greece & $x$ & & \\
\hline New railway station of Thessaloniki & Greece & & $x$ & $\times$ \\
\hline Intercity Coaches of Magnesia & Greece & & $x$ & $x$ \\
\hline Macedonia Coach terminal & Greece & & $x$ & $\times$ \\
\hline
\end{tabular}


End of Table 1

\begin{tabular}{|c|c|c|c|c|}
\hline \multirow[b]{2}{*}{ Interchange name } & \multirow[b]{2}{*}{ Country } & \multicolumn{3}{|c|}{ Interchange type } \\
\hline & & $\begin{array}{l}\text { National } \\
\text { hub }\end{array}$ & $\begin{array}{l}\text { National city } \\
\text { terminal }\end{array}$ & $\begin{array}{l}\text { Other city or local } \\
\text { terminals }\end{array}$ \\
\hline Railway station of Volos & Greece & & $x$ & $\times$ \\
\hline KTEL Kifisou & Greece & & $x$ & $x$ \\
\hline Köbánya-Kispest interchange terminal & Hungary & & $\times$ & $\times$ \\
\hline Intermodal terminal of Miskolc & Hungary & & $\times$ & $x$ \\
\hline Vilnius airport & Lithuania & $\times$ & & \\
\hline Oslo bus terminal Vaterland & Norway & & $\times$ & $\times$ \\
\hline Gare De Oriente & Portugal & & $x$ & $x$ \\
\hline Moncloa interchange & Spain & & $\times$ & $\times$ \\
\hline Paseo de Gracia & Spain & & $\times$ & $x$ \\
\hline Plaza Castilla Interchange & Spain & & $x$ & $x$ \\
\hline Madrid Airport Barajas T4 & Spain & $\times$ & & \\
\hline Zurich central station & Switzerland & & $x$ & $x$ \\
\hline Zurich airport & Switzerland & $\times$ & & \\
\hline Den Bosch train station & The Netherlands & & $x$ & $\times$ \\
\hline Utrecht Central & The Netherlands & & $x$ & $\times$ \\
\hline Birmingham New Street Station & United Kingdom & & $\times$ & $\times$ \\
\hline King's Cross St Pancras Underground Station & United Kingdom & & $\times$ & $\times$ \\
\hline Ilford railway station & United Kingdom & & $x$ & $x$ \\
\hline London Stansted Airport & United Kingdom & $x$ & & \\
\hline
\end{tabular}

Table 2. Overview of passenger interchanges in Latvia

\begin{tabular}{|l|l|c|c|c|}
\hline \multicolumn{1}{|c|}{ Interchange name } & \multirow{2}{*}{ Country } & \multicolumn{3}{c|}{ Interchange type } \\
\cline { 4 - 5 } & & $\begin{array}{c}\text { National } \\
\text { hub }\end{array}$ & $\begin{array}{c}\text { National city } \\
\text { terminal }\end{array}$ & $\begin{array}{c}\text { Other city or local } \\
\text { terminals }\end{array}$ \\
\hline Riga International Coach Terminal & Latvia & $\times$ & & $\times$ \\
\hline Intermodal transport interchange at Alfa shopping center & Latvia & & $\times$ & \\
\hline Riga International Airport & Latvia & $\times$ & & $\times$ \\
\hline Noord Natie Ventspils Terminals & Latvia & & & $\times$ \\
\hline Sigulda bus and train terminal & Latvia & & & $\times$ \\
\hline
\end{tabular}

Table 3. Overview of freight interchanges in European Union

\begin{tabular}{|c|c|c|c|c|c|}
\hline \multirow[b]{2}{*}{ Interchange name } & \multirow[b]{2}{*}{ Country } & \multicolumn{4}{|c|}{ Interchange type } \\
\hline & & $\begin{array}{c}\text { Special logistic } \\
\text { area }\end{array}$ & $\begin{array}{l}\text { Industrial and } \\
\text { logistic park }\end{array}$ & $\begin{array}{c}\text { Freight } \\
\text { village }\end{array}$ & $\begin{array}{c}\text { City } \\
\text { terminal }\end{array}$ \\
\hline HøjeTaastrup rail freight terminal & Denmark & $\times$ & & & \\
\hline Port of Helsinki Vuosaari & Finland & $x$ & & & \\
\hline Sogaris freght centers & France & & & $x$ & \\
\hline Garonor freight centers & France & & & $x$ & \\
\hline Leipzig-Halle airport & Germany & $x$ & & & \\
\hline GVD freight centers & Germany & & & $\times$ & \\
\hline Thessaloniki port & Greece & $\times$ & $x$ & & \\
\hline Thriassio consolidation center & Greece & $x$ & & & \\
\hline Trigono consolidation center & Greece & $x$ & & & \\
\hline Kuehne \& Nagel freight terminal & Greece & $\times$ & & & \\
\hline Interporto Bologna S.p.A. & Italy & & & $x$ & \\
\hline Constantza port & Romania & $x$ & & & \\
\hline DHL Urban Consolidation Center & Spain & $x$ & & & \\
\hline
\end{tabular}


Table 4. Overview of freight interchanges in Latvia and the Region

\begin{tabular}{|c|c|c|c|c|c|}
\hline \multirow[b]{2}{*}{ Interchange name } & \multirow[b]{2}{*}{ Country } & \multicolumn{4}{|c|}{ Interchange type } \\
\hline & & $\begin{array}{c}\text { Special logistic } \\
\text { area }\end{array}$ & $\begin{array}{l}\text { Industrial and } \\
\text { logistic park }\end{array}$ & $\begin{array}{l}\text { Freight } \\
\text { village }\end{array}$ & $\begin{array}{c}\text { City } \\
\text { terminal }\end{array}$ \\
\hline Baltic Coal Terminal & Latvia & $\times$ & & $x$ & \\
\hline Noord Natie Ventspils Terminals & Latvia & $\times$ & & $x$ & \\
\hline Latvian Post sorting complex & Latvia & & & $x$ & $x$ \\
\hline Rimi Latvia distribution center & Latvia & $x$ & & & \\
\hline Vilnius Intermodal Terminal & Lithuania & $x$ & & & \\
\hline
\end{tabular}

\subsection{Freight Interchanges}

For the EU, the review included 13 freight interchanges located in eight European countries: Denmark, Finland, France, Germany, Greece, Italy, Romania and Spain. A summary of good practices and its categorizations according to four types of transport and logistics terminals suggested by the European project REFORM (EC 1999) are given in Table 3. For the Latvia and the region, existing freight terminals were chosen as good practices. The list of these terminals is shown in Table 4.

\section{Educational Programs Identification and Selection}

Educational programs, which were selected for detailed revision, satisfied a set of qualitative criteria, as follows (the order reflects the priority that was given to each category):

- Relevance to transport programs. According to the organization proposed in Horizon 2020 these should cover one of the following transport modes: road, urban, waterborne, aviation, intermodal or rail).

- Transport program focus. According to the available European Union transport programs, identified programs were divided in two categories: 'Generic' and 'Specialized'. Generic transport programs refer to all transportation planning and engineering programs, whereas specialized include all others, which were found usually to focus on Logistics, Business and Management. The survey was designed and conducted on educational institutes, which are active in providing generic and specialized knowledge on intermodal transport, terminals and logistics, in regards to planning and operation. The share of generic and specialized transport programs is roughly equal, with 26 generic and 27 specialized transport programs.

- Coverage of different geographical areas. A panEuropean coverage was attempted.

- Program focus: This refers to balance between generic and specialized transport programs and minimum number of five programs per 'focus' category.
- Data availability and accessibility. The following information should be easily retrieved: goals, objectives, learning outcomes, course description, suggested bibliography, teaching and assessment methods.

- Language of the program. English was the preferred language since these programs attract more foreign and international students.

- Coverage of well-reputed educational institutes and transport programs.

\subsection{European Union}

Applying all criteria, the 53 identified postgraduate programs narrowed down to 18 programs, which indicates a selection rate of $34 \%$. To disaggregate available information and perform a comprehensive gap analysis the transport programs were reviewed in terms of offered courses. In all of the 18 transport programs, 114 courses were identified to be relevant to the scope of this study, according to their syllabus, thus related to interconnecting transport networks. These are either core, mandatory or optional courses.

\subsection{Latvia and the Region}

For Latvia, Lithuania, Estonia and Poland, 114 transport related programs were found in Latvia, Lithuania, Estonia and Poland. Most transport education and training programs in the universities of the Baltic States and Poland are undergraduate and professional programs. Educational coverage of new technologies in the transport area (i.e., intelligent transport systems, ICT technologies, etc.) is not adequate in Latvian and region's transport education programs. The thematic area 'Smart solutions' for interconnection of transport networks is practically limited from transport programs' content and courses, relative to the other two thematic areas (i.e., governance and decision-making). Approximately $28 \%$ of the courses that focus on one of the other two thematic areas cover simultaneously the area of smart solutions.

The courses as part of the selected educational and training programs were grouped in the three thematic areas:

- governance and policy development;

- smart solutions;

- decision-making. 
Research on educational postgraduate transport courses in European Union has shown that 59\%, 34\% and $52 \%$ of the courses focus on 'Governance and policy development', 'Smart solutions' and 'Decision-making', respectively. However, it was noticed that multiple courses cover more than one thematic area in most cases. More specifically, $25 \%$ and $31 \%$ of transport courses on 'Governance and policy development' cover 'Smart solutions' and 'Decision-making' as well. Similarly, 43\% of transport courses on 'Smart solutions' cover additionally 'Governance and policy development' and 'Decision-making' and $34 \%$ and $28 \%$ of transport courses on decision-making cover additionally 'Governance and policy development' and 'Smart solutions', respectively. European Union based courses at postgraduate level were found to cover very often more than one thematic area. The number of transport environmental courses are four times higher in European Union compared to Latvia and the region, and in most cases, they appear to provide a well-structured course that embraces at least two thematic areas, simultaneously. On the other hand, Latvia and the region include a much higher number of transport engineering courses in their programs compared to European Union.

\section{Analysis and Results}

Different gap analysis strategies have been developed and applied in order to assess the steps that need to be taken to achieve future goals and objectives (Mineraud et al. 2016). The McKinsey 7S Framework is applied at business level to examine its characteristics through seven people-centric groupings: strategy, structure, systems, staff, style, skills and shared values (Rouse 2014). The SWOT ('Strengths', 'Weaknesses', 'Opportunities' and 'Threats') has also been used in gap analysis to maximize strengths while minimizing weaknesses and avoiding threats. The Nadler-Tushman model or congruence model is a dynamic model that suggests that for identifying potential gaps in a system, the way that key organizational components of the system fit together should be studied; thus components' interactions are more important than the components itself (MDC 2003).

The gap analysis in this study is implemented in two levels to determine the gaps that might exist between (1) the interconnecting networks in European Union and the Latvia and the region, and (2) the interconnecting networks in European Union and the Latvia and the region (i.e., Gap analysis I), and the existing research, educational and training programs in Latvia and the region. The gap analysis for both the current interconnecting networks and the research, educational and training programs is performed with respect to the three thematic areas: (1) governance and policy, (2) smart solutions, and (3) decision-making. Each thematic area is divided in topics that are used to organize the collected information on transport interchanges and facilitate the analysis by providing specific requirements per thematic area and topic.

\subsection{GAP Analysis I}

The results from Gap analysis I for passenger interchanges are summarized in Table 5. The gaps are identified by comparing the practices between the European Union and the Latvian and region; for each identified gap, a requirement is formulated to encounter or deal per corresponding gap. Similarly, to passenger interchanges, Table 6 presents the gaps and requirements for each of the thematic areas and topic for freight interchanges.

\subsection{GAP Analysis II}

Results of the first level gap analysis were combined with existing research, educational and training transport programs in Latvia and the region to identify potential gaps in the aims and content offered by these educational programs as compared with practice requirements. Table 7 converts the gaps identified in Gap analysis I for both for passenger and freight interchanges, into educational requirements. The requirements in Table 7 are the outcome of Gap analysis II.

Existing research, educational and training programs in transport in Latvia and the region present an adequate coverage of traditional transport principles and the generic methods that are used in transport for planning and design. However, these courses are not specialized on intermodality. Additionally, the environmental courses appear to be scarce for covering transportation planning and design in accordance to European Union legislation. Knowledge is required that describes, measures, and quantifies the environmental impacts of individual behaviour, of transport policies and projects and skills to disaggregate the inter-relationships between sustainability, the environment, energy and transport.

On overall, Latvia and the region are found to have limited and non-well-functioning educational networks among institutes at national as well as international level with the aim of increasing the competence of educational system in the area of international transport. Increasing the number of courses offered in English is expected to enhance education visibility and enable international cooperation. Finally, the development of special courses for vocational transport training to support distance learning will create incentives to practitioners and stakeholders to improve their knowledge and skills and adopt state-of-the-art solutions in interconnecting transport networks successfully.

The variety of postgraduate transport courses in European Union shows that European Union educational institutions tend to provide well integrated transport courses and the majority of them, either generic or specialized programs, promote the incorporation of technological advances and European Union legislation. The European Union educational experience shows that has the potential to support actions for addressing deficiencies for the Latvia and the region. For example, for rail-based courses the European Union programs were found to provide well-structured content. Such knowledge could cover the process of rail planning and building, methods to create a timetable for the railway, 
economic analysis of passenger and freight transport on the railway. In the same way as transport systems and services, evolve within a European framework, transport education and training need to change its content to adopt to new socioeconomic and technological conditions by taking into account international aspects and globalization and move from conventional to networked environments.

Table 5. Identification of gaps/requirements for passenger interchanges

\begin{tabular}{|c|c|c|c|c|c|}
\hline $\begin{array}{l}\text { Thematic } \\
\text { area }\end{array}$ & Topic & European Union practices & $\begin{array}{c}\text { Latvia and region - state } \\
\text { of practice }\end{array}$ & Gap I & Requirement \\
\hline \multirow{6}{*}{ 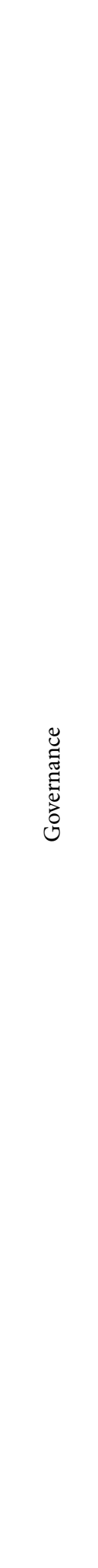 } & $\begin{array}{l}\text { Stake- } \\
\text { holders }\end{array}$ & $\begin{array}{l}\text { Clear identification of the } \\
\text { roles and responsibilities } \\
\text { of multiple stakeholders. } \\
\text { Use of concession contracts } \\
\text { for the organization of the } \\
\text { station operation. }\end{array}$ & $\begin{array}{l}\text { Roles and responsibilities } \\
\text { clearly identified (e.g. in } \\
\text { Riga International Airport). } \\
\text { Various types of } \\
\text { participation available. }\end{array}$ & & \\
\hline & Policy & $\begin{array}{l}\text { When the municipality } \\
\text { has clear roles and } \\
\text { responsibilities, then it can } \\
\text { lead the processes at an } \\
\text { interchange and bring in } \\
\text { funding sources, if needed. } \\
\text { National and regional } \\
\text { authorities make efforts to } \\
\text { familiarize transport and } \\
\text { terminal operators with } \\
\text { relevant policies. }\end{array}$ & $\begin{array}{l}\text { National/regional/local } \\
\text { policies for strategic } \\
\text { development exist. } \\
\text { National and local } \\
\text { authorities have interest in } \\
\text { establishment of interchange } \\
\text { terminals (e.g. in Sigulda } \\
\text { bus and train terminal). }\end{array}$ & $\begin{array}{l}\text { Legal framework } \\
\text { does not focus on } \\
\text { interchanges. }\end{array}$ & $\begin{array}{l}\text { Harmonization } \\
\text { of policies. }\end{array}$ \\
\hline & $\begin{array}{l}\text { Owner- } \\
\text { ship }\end{array}$ & $\begin{array}{l}\text { Pursuit of public/ } \\
\text { private model to ensure } \\
\text { that the operations and } \\
\text { management are co- } \\
\text { ordinated across all the } \\
\text { transport and other } \\
\text { functions. } \\
\text { Organizing the } \\
\text { relationships between } \\
\text { public and private } \\
\text { according to the local } \\
\text { context and functions of } \\
\text { the interchange. } \\
\text { Ownership separation from } \\
\text { operation. }\end{array}$ & $\begin{array}{l}\text { Limited involvement of } \\
\text { private investors due to } \\
\text { small market. } \\
\text { Restriction on the use of the } \\
\text { public-private partnership } \\
\text { model by the government. } \\
\text { Poor use of public-private } \\
\text { partnerships. }\end{array}$ & $\begin{array}{l}\text { Limited involvement } \\
\text { of several } \\
\text { authorities. }\end{array}$ & $\begin{array}{l}\text { Building incentives } \\
\text { and opening } \\
\text { opportunities } \\
\text { for investors. }\end{array}$ \\
\hline & $\begin{array}{l}\text { Sustain- } \\
\text { able } \\
\text { develop- } \\
\text { ment }\end{array}$ & $\begin{array}{l}\text { Involvement of private } \\
\text { sector and pursuit of } \\
\text { private funding. } \\
\text { Development plan for city } \\
\text { integration. }\end{array}$ & $\begin{array}{l}\text { Development plans include } \\
\text { integration of transport } \\
\text { sector at the municipality } \\
\text { level, not enough emphasis } \\
\text { on integration of transport } \\
\text { modes at the national level. }\end{array}$ & $\begin{array}{l}\text { Limited } \\
\text { incorporation of } \\
\text { interchanges in } \\
\text { urban and rural } \\
\text { development plans. }\end{array}$ & $\begin{array}{l}\text { Integrated } \\
\text { development } \\
\text { planning. }\end{array}$ \\
\hline & $\begin{array}{l}\text { Manage- } \\
\text { ment }\end{array}$ & $\begin{array}{l}\text { Development of } \\
\text { Interchange Management } \\
\text { Plan. }\end{array}$ & $\begin{array}{l}\text { Fragmented existence of } \\
\text { Interchange Management } \\
\text { Plan; may not cover all } \\
\text { aspects of functionalities. } \\
\text { The cities and the } \\
\text { government of Latvia are } \\
\text { eager to better control } \\
\text { their subsidies to public } \\
\text { transports companies, } \\
\text { and they need automatic } \\
\text { passenger counter systems } \\
\text { widely accepted across the } \\
\text { country. }\end{array}$ & $\begin{array}{l}\text { Interchange } \\
\text { Management Plan } \\
\text { not including } \\
\text { all aspects of } \\
\text { interchange } \\
\text { functionalities and } \\
\text { interests. }\end{array}$ & $\begin{array}{l}\text { Enrichment of } \\
\text { Interchange Master } \\
\text { Plan. }\end{array}$ \\
\hline & $\begin{array}{l}\text { Opera- } \\
\text { tion }\end{array}$ & $\begin{array}{l}\text { Integrated coordination } \\
\text { among transport operators } \\
\text { and modes. }\end{array}$ & $\begin{array}{l}\text { Poor operation integration } \\
\text { among various operators at } \\
\text { the state level. }\end{array}$ & $\begin{array}{l}\text { Limited } \\
\text { coordination } \\
\text { among modes } \\
\text { and operators at } \\
\text { the regional and } \\
\text { national levels. }\end{array}$ & $\begin{array}{l}\text { Promoting } \\
\text { operational } \\
\text { integration. }\end{array}$ \\
\hline
\end{tabular}


End of Table 5

\begin{tabular}{|c|c|c|c|c|c|}
\hline $\begin{array}{c}\text { Thematic } \\
\text { area }\end{array}$ & Topic & European Union practices & $\begin{array}{l}\text { Latvia and region - state } \\
\text { of practice }\end{array}$ & Gap I & Requirement \\
\hline \multirow{3}{*}{ 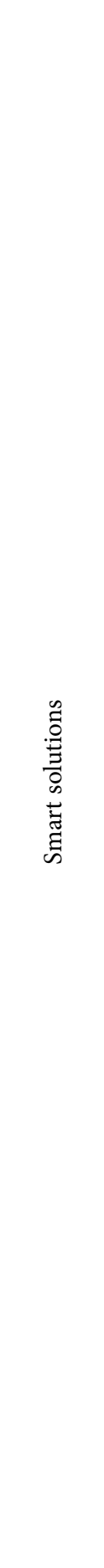 } & $\begin{array}{l}\text { Informa- } \\
\text { tion }\end{array}$ & $\begin{array}{l}\text { Real time information: } \\
\text { pre-trip planning, } \\
\text { electric departure time } \\
\text { display, multi-language } \\
\text { information. } \\
\text { Way finding plan: maps, } \\
\text { floor plans, directional } \\
\text { signals (WC, ticket } \\
\text { booth, concise, clear, } \\
\text { consistent and ambiguous } \\
\text { information). }\end{array}$ & $\begin{array}{l}\text { Smart solutions applied } \\
\text { fragmentarily. } \\
\text { Basic information is } \\
\text { provided. }\end{array}$ & $\begin{array}{l}\text { Limited multimodal } \\
\text { information at } \\
\text { the regional and } \\
\text { national levels. }\end{array}$ & $\begin{array}{l}\text { Providing integrated } \\
\text { information at the } \\
\text { national level. }\end{array}$ \\
\hline & Services & $\begin{array}{l}\text { Integrating ticketing: ticket } \\
\text { sale for all services in the } \\
\text { interchange facility zone, } \\
\text { definition of fare paid } \\
\text { areas, staff presence, smart } \\
\text { ticket readers. } \\
\text { Safety: design covering all } \\
\text { emergency and security } \\
\text { requirements (handrails, } \\
\text { anti-sleep flooring, and } \\
\text { lighting), avoidance } \\
\text { of conflicts between } \\
\text { pedestrians and vehicles, } \\
\text { emergency management } \\
\text { plan amongst stakeholders, } \\
\text { trained staff, emergency } \\
\text { exits. } \\
\text { Security: consultation of } \\
\text { crime prevention specialists } \\
\text { during the design phase, } \\
\text { consideration of crime } \\
\text { prevention through } \\
\text { environmental design, good } \\
\text { lighting, CCTV, trained key } \\
\text { staff presence. }\end{array}$ & $\begin{array}{l}\text { Different ticketing systems } \\
\text { developed for various } \\
\text { modes of transport (e.g. in } \\
\text { Riga International Coach } \\
\text { Terminal). } \\
\text { Design in terms of safety } \\
\text { does not correspond to } \\
\text { today's requirements in } \\
\text { cases of old passenger } \\
\text { interchanges. } \\
\text { Average level of security is } \\
\text { provided. }\end{array}$ & $\begin{array}{l}\text { Limited integrating } \\
\text { ticketing. } \\
\text { Existing services } \\
\text { do not offer } \\
\text { traveller real-time } \\
\text { information across } \\
\text { all stages of a } \\
\text { multimodal trip. } \\
\text { Possible conflicts } \\
\text { between vehicles } \\
\text { and pedestrians. } \\
\text { Not sufficient } \\
\text { security level. }\end{array}$ & $\begin{array}{l}\text { Policy development } \\
\text { for integrated } \\
\text { ticketing at the } \\
\text { national level. } \\
\text { Real-time information } \\
\text { for support door-to- } \\
\text { door trip on all stages } \\
\text { of planning and } \\
\text { implementation. } \\
\text { To be more integrated } \\
\text { with the help of the } \\
\text { same technological } \\
\text { platforms: ticket } \\
\text { validation systems, } \\
\text { based on rechargeable } \\
\text { and contactless } \\
\text { e-cards, and real- } \\
\text { time information } \\
\text { system for all modes } \\
\text { of transport, either } \\
\text { in panels at stops or } \\
\text { stations, or via smart } \\
\text { phone applications. } \\
\text { Spatial separation of } \\
\text { passengers' movement } \\
\text { from movement of } \\
\text { transport means. } \\
\text { Increasing } \\
\text { monitoring, warning } \\
\text { and presence of police } \\
\text { and interchange staff. }\end{array}$ \\
\hline & $\begin{array}{l}\text { Physical } \\
\text { proper- } \\
\text { ties }\end{array}$ & $\begin{array}{l}\text { Appropriate design and } \\
\text { layout of access/egress. } \\
\text { Accessibility for all users. } \\
\text { Environmental concerns } \\
\text { and energy efficiency. } \\
\text { Variety and high quality } \\
\text { facilities. }\end{array}$ & $\begin{array}{l}\text { Design and layout of access } \\
\text { varies depending on facility's } \\
\text { age. } \\
\text { Energy efficiency is taken } \\
\text { into account for new } \\
\text { projects. }\end{array}$ & $\begin{array}{l}\text { Limited access for } \\
\text { all users. } \\
\text { Insufficient cycling } \\
\text { and walking } \\
\text { facilities. } \\
\text { Environmental } \\
\text { concerns vary } \\
\text { depending on } \\
\text { facilities' age. }\end{array}$ & $\begin{array}{l}\text { Improving } \\
\text { accessibility for all } \\
\text { user groups providing } \\
\text { more flexible and } \\
\text { individualized service. } \\
\text { Designing and } \\
\text { implementing } \\
\text { walking and cycling } \\
\text { facilities. } \\
\text { Development of } \\
\text { energy efficiency plan. }\end{array}$ \\
\hline 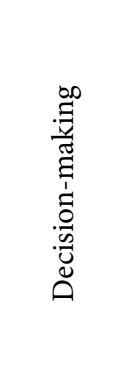 & $\begin{array}{l}\text { Inter- } \\
\text { change } \\
\text { status as- } \\
\text { sessment } \\
\text { and users' } \\
\text { feedback }\end{array}$ & $\begin{array}{l}\text { Pursuit of public } \\
\text { participation. } \\
\text { Customer satisfaction } \\
\text { surveys. }\end{array}$ & $\begin{array}{l}\text { User feedback is used } \\
\text { fragmentarily (e.g. in } \\
\text { International transport } \\
\text { interchange at Alfa shopping } \\
\text { center). }\end{array}$ & $\begin{array}{l}\text { Not obligatory. } \\
\text { Insufficient } \\
\text { information for } \\
\text { decision-making: } \\
\text { only few surveys, } \\
\text { data not reliable; } \\
\text { no network } \\
\text { assessment at the } \\
\text { strategic level, etc. } \\
\text { Limited data } \\
\text { sharing. }\end{array}$ & $\begin{array}{l}\text { Enhancement } \\
\text { of customers' } \\
\text { satisfaction surveys. } \\
\text { Public realm } \\
\text { improvement scheme. } \\
\text { Exploitation of big } \\
\text { data opportunities. }\end{array}$ \\
\hline
\end{tabular}


Table 6. Identification of gaps/requirements for freight interchanges

\begin{tabular}{|c|c|c|c|c|c|}
\hline $\begin{array}{l}\text { Thematic } \\
\text { area }\end{array}$ & Topic & European Union practices & $\begin{array}{l}\text { Latvia and region - state } \\
\text { of practice }\end{array}$ & Gap I & Requirement \\
\hline \multirow{6}{*}{ 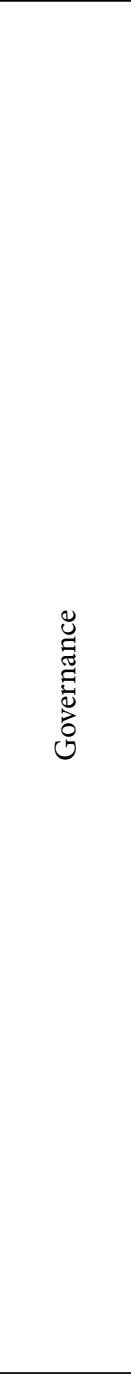 } & $\begin{array}{l}\text { Stakehold- } \\
\text { ers }\end{array}$ & $\begin{array}{l}\text { Absence of clear } \\
\text { identification of the roles } \\
\text { and responsibilities of } \\
\text { multiple stakeholders. }\end{array}$ & $\begin{array}{l}\text { Roles and responsibilities } \\
\text { clearly identified (e.g. in Rimi } \\
\text { Latvia distribution center). }\end{array}$ & & \\
\hline & Policy & Not harmonized policy. & $\begin{array}{l}\text { National transport policies } \\
\text { are in line with the European } \\
\text { Union transport policy. } \\
\text { Fragmented focus on } \\
\text { intermodality, in some } \\
\text { cases effective integration of } \\
\text { different modes of transport } \\
\text { (e.g. in Vilnius Intermodal } \\
\text { Terminal). } \\
\text { Segmented policy on tariffs } \\
\text { (for different transport } \\
\text { modes). }\end{array}$ & $\begin{array}{l}\text { Not harmonized } \\
\text { policy for } \\
\text { interchanges. }\end{array}$ & $\begin{array}{l}\text { Harmonization of } \\
\text { policies. }\end{array}$ \\
\hline & $\begin{array}{l}\text { Owner- } \\
\text { ship }\end{array}$ & $\begin{array}{l}\text { Access to all companies } \\
\text { to terminals under equal } \\
\text { conditions of ownership. }\end{array}$ & $\begin{array}{l}\text { Public and private ownership. } \\
\text { Poor use of public-private } \\
\text { partnerships. }\end{array}$ & $\begin{array}{l}\text { Limited } \\
\text { business models } \\
\text { development. }\end{array}$ & $\begin{array}{l}\text { Development of } \\
\text { business models for } \\
\text { different ownership } \\
\text { schemes. }\end{array}$ \\
\hline & $\begin{array}{l}\text { Sustain- } \\
\text { able devel- } \\
\text { opment }\end{array}$ & $\begin{array}{l}\text { Involvement of private } \\
\text { sector and pursuit of } \\
\text { private funding. }\end{array}$ & $\begin{array}{l}\text { Sustainable development is } \\
\text { foreseen in strategic plans } \\
\text { (e.g. in Noord Natie Ventspils } \\
\text { Terminals). }\end{array}$ & $\begin{array}{l}\text { Limited } \\
\text { incorporation } \\
\text { of interchanges } \\
\text { in regional } \\
\text { and national } \\
\text { development plans. }\end{array}$ & $\begin{array}{l}\text { Integrated } \\
\text { development } \\
\text { planning. }\end{array}$ \\
\hline & $\begin{array}{l}\text { Manage- } \\
\text { ment }\end{array}$ & $\begin{array}{l}\text { Development of Master } \\
\text { Plan. }\end{array}$ & $\begin{array}{l}\text { Master Plan exists for each } \\
\text { freight terminal. }\end{array}$ & & $\begin{array}{l}\text { Enhancing } \\
\text { administrative and } \\
\text { cooperative schemes } \\
\text { between public and } \\
\text { private sector. }\end{array}$ \\
\hline & Operation & $\begin{array}{l}\text { Integrated coordination } \\
\text { among transport } \\
\text { operators and modes. }\end{array}$ & $\begin{array}{l}\text { Provision of high-level } \\
\text { productivity, fast and reliable } \\
\text { services } \\
\text { Effective integration of } \\
\text { different transport modes (e.g. } \\
\text { Vilnius Intermodal Terminal). }\end{array}$ & & $\begin{array}{l}\text { Enhance } \\
\text { administrative and } \\
\text { cooperative schemes } \\
\text { between public and } \\
\text { private sector. }\end{array}$ \\
\hline \multirow{2}{*}{ 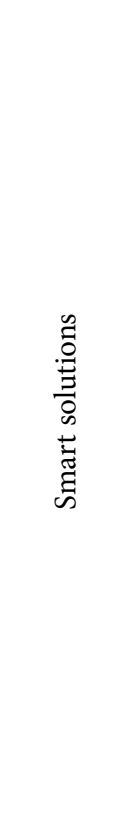 } & $\begin{array}{l}\text { New con- } \\
\text { solidation/ } \\
\text { distribu- } \\
\text { tion and } \\
\text { logistics } \\
\text { coopera- } \\
\text { tive con- } \\
\text { cepts }\end{array}$ & $\begin{array}{l}\text { Establishment of urban } \\
\text { consolidation centers. } \\
\text { Business and transport } \\
\text { operational plan. }\end{array}$ & $\begin{array}{l}\text { Consolidated distribution } \\
\text { centers continue to develop } \\
\text { (e.g. in Rimi Latvia } \\
\text { distribution center). }\end{array}$ & $\begin{array}{l}\text { Individually } \\
\text { planned urban } \\
\text { consolidation } \\
\text { centers. } \\
\text { Limited business } \\
\text { and transport } \\
\text { operational } \\
\text { planning. }\end{array}$ & $\begin{array}{l}\text { Development of a } \\
\text { rational strategic } \\
\text { plan of urban } \\
\text { consolidation/ } \\
\text { distribution centers } \\
\text { taking into account } \\
\text { market demand. } \\
\text { Establishment of } \\
\text { coherent cooperative } \\
\text { logistics schemes. } \\
\end{array}$ \\
\hline & $\begin{array}{l}\text { Informa- } \\
\text { tion tech- } \\
\text { nologies }\end{array}$ & $\begin{array}{l}\text { Use of Information } \\
\text { and Communication } \\
\text { Technologies for } \\
\text { developing Truck } \\
\text { Management Systems and } \\
\text { Warehouse Management } \\
\text { Systems. }\end{array}$ & $\begin{array}{l}\text { IT systems introduced } \\
\text { and used for supply-chain } \\
\text { management, trip planning } \\
\text { and fleet management, e.g. } \\
\text { in Rimi Latvia distribution } \\
\text { center, high standard } \\
\text { technologies in Noord Natie } \\
\text { Ventpils Terminals. }\end{array}$ & $\begin{array}{l}\text { Limited } \\
\text { cooperation } \\
\text { between } \\
\text { publicly owned } \\
\text { and operated } \\
\text { Intelligent } \\
\text { Transport Systems } \\
\text { and enterprise- } \\
\text { level software } \\
\text { for supply-chain } \\
\text { management, trip } \\
\text { planning and fleet } \\
\text { management. }\end{array}$ & $\begin{array}{l}\text { Promotion of } \\
\text { cooperative logistics } \\
\text { solutions and other } \\
\text { smart solutions. }\end{array}$ \\
\hline
\end{tabular}


End of Table 6

\begin{tabular}{|c|c|c|c|c|c|}
\hline $\begin{array}{l}\text { Thematic } \\
\text { area }\end{array}$ & Topic & European Union practices & $\begin{array}{l}\text { Latvia and region - state } \\
\text { of practice }\end{array}$ & Gap I & Requirement \\
\hline 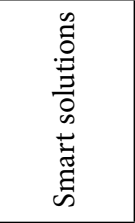 & $\begin{array}{l}\text { Smart } \\
\text { tranship- } \\
\text { ment }\end{array}$ & $\begin{array}{l}\text { Use of equipment for } \\
\text { loading-unloading } \\
\text { operations and } \\
\text { movements within the } \\
\text { interchange facilities. }\end{array}$ & $\begin{array}{l}\text { Use of equipment for loading- } \\
\text { unloading operations and } \\
\text { movements. } \\
\text { Fragmented use of energy } \\
\text { effective and environmentally } \\
\text { friendly equipment. }\end{array}$ & $\begin{array}{l}\text { Limited use } \\
\text { of alternative, } \\
\text { friendly to } \\
\text { environment and } \\
\text { energy equipment. }\end{array}$ & $\begin{array}{l}\text { Application of } \\
\text { alternative fuels } \\
\text { and propulsion } \\
\text { technologies. }\end{array}$ \\
\hline 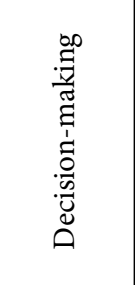 & $\begin{array}{l}\text { Decision- } \\
\text { support } \\
\text { methods }\end{array}$ & $\begin{array}{l}\text { Agent-based modelling } \\
\text { approach and multi- } \\
\text { stakeholder multi-criteria } \\
\text { analysis. }\end{array}$ & $\begin{array}{l}\text { Several decision support tools } \\
\text { used such as environmental } \\
\text { impact assessment, traffic } \\
\text { forecasting, economic analysis } \\
\text { and risk assessment (e.g. in } \\
\text { Baltic Coal Terminal). } \\
\text { Fragmented data collection } \\
\text { and analysis. }\end{array}$ & $\begin{array}{l}\text { Limited sharing of } \\
\text { data. }\end{array}$ & $\begin{array}{l}\text { Exploitation of BIG } \\
\text { data opportunities. }\end{array}$ \\
\hline
\end{tabular}

Table 7. Educational requirements for Latvia and the region (Gap analysis II)

\begin{tabular}{|c|c|c|c|c|}
\hline $\begin{array}{c}\text { Thematic } \\
\text { area }\end{array}$ & Topic & Gap I & Educational requirement & Educational areas \\
\hline \multirow{9}{*}{ 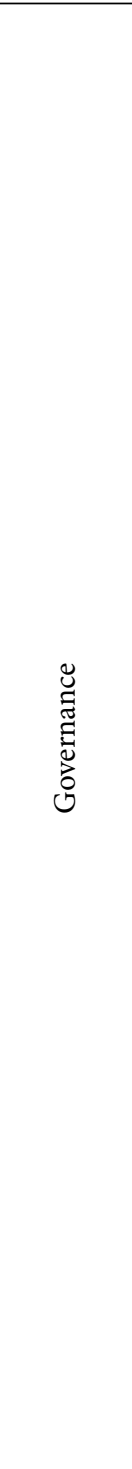 } & $\begin{array}{l}\text { Stake- } \\
\text { holders }\end{array}$ & & $\begin{array}{l}\text { Incorporation of organizational and business } \\
\text { models in course material. }\end{array}$ & $\begin{array}{l}\text { 1. Building business models } \\
\text { for passenger transport } \\
\text { interchanges. }\end{array}$ \\
\hline & \multirow[t]{2}{*}{ Policy } & $\begin{array}{l}\text { Legal framework } \\
\text { does not focus on } \\
\text { interchanges. }\end{array}$ & $\begin{array}{l}\text { Improvement of course content on transport } \\
\text { legal frameworks with reference to European } \\
\text { Union and partial coverage of interchanges and } \\
\text { environmental legislation. } \\
\text { Special attention on interchanges and } \\
\text { environmental legislation in the courses } \\
\text { oriented on European Union transport policy } \\
\text { issues. }\end{array}$ & $\begin{array}{l}\text { 2. Development and } \\
\text { implementation of } \\
\text { sustainability and } \\
\text { transport. policies in the } \\
\text { European Union region. }\end{array}$ \\
\hline & & $\begin{array}{l}\text { Not harmonized policy } \\
\text { for interchanges. }\end{array}$ & $\begin{array}{l}\text { Improvement of course content on transport } \\
\text { legal frameworks with reference to EU, freight } \\
\text { transport and environmental legislation }\end{array}$ & $\begin{array}{l}\text { 3. Development and } \\
\text { implementation of freight } \\
\text { transport policies in the } \\
\text { European Union region. }\end{array}$ \\
\hline & \multirow[t]{2}{*}{$\begin{array}{l}\text { Owner- } \\
\text { ship }\end{array}$} & $\begin{array}{l}\text { Limited involvement of } \\
\text { several authorities. }\end{array}$ & $\begin{array}{l}\text { Incorporation of courses oriented on Public } \\
\text { Private Partnerships (PPP) models and mega } \\
\text { infrastructure financing schemes in educational } \\
\text { and training the program. }\end{array}$ & $\begin{array}{l}\text { 4. PPP in transport: theory } \\
\text { and schemes. }\end{array}$ \\
\hline & & $\begin{array}{l}\text { Limited business models } \\
\text { development. }\end{array}$ & $\begin{array}{l}\text { Incorporation of innovative business models in } \\
\text { course material. }\end{array}$ & $\begin{array}{l}\text { 5. Building business models } \\
\text { for freight transport } \\
\text { interchanges. }\end{array}$ \\
\hline & \multirow[t]{2}{*}{$\begin{array}{l}\text { Sustain- } \\
\text { able } \\
\text { develop- } \\
\text { ment }\end{array}$} & $\begin{array}{l}\text { Limited incorporation } \\
\text { of interchanges in } \\
\text { regional and national } \\
\text { development plans. }\end{array}$ & $\begin{array}{l}\text { Incorporation in the program of topics with } \\
\text { integrated development plans with reference to } \\
\text { sustainable development and the environment. }\end{array}$ & $\begin{array}{l}\text { 6. Sustainable passenger } \\
\text { transportation planning. }\end{array}$ \\
\hline & & $\begin{array}{l}\text { Limited incorporation } \\
\text { of interchanges in } \\
\text { regional and national } \\
\text { development plans. }\end{array}$ & $\begin{array}{l}\text { Incorporation in the program topics with } \\
\text { integrated development plans with reference to } \\
\text { sustainable development and the environment. }\end{array}$ & $\begin{array}{l}\text { 7. Sustainable freight } \\
\text { transportation planning. }\end{array}$ \\
\hline & \multirow[t]{2}{*}{$\begin{array}{l}\text { Manage- } \\
\text { ment }\end{array}$} & $\begin{array}{l}\text { Interchange Management } \\
\text { Plan not including all } \\
\text { aspects of interchange } \\
\text { functionalities and } \\
\text { interests. }\end{array}$ & $\begin{array}{l}\text { Development of material on integrated } \\
\text { coordination and operation of mega } \\
\text { infrastructure facilities with special reference } \\
\text { to interchanges and the utilization of } \\
\text { technological advances. }\end{array}$ & $\begin{array}{l}\text { 8. Operation and } \\
\text { management of urban } \\
\text { public transport systems. }\end{array}$ \\
\hline & & & $\begin{array}{l}\text { Incorporation of innovative business and } \\
\text { management models in course material. }\end{array}$ & $\begin{array}{l}\text { 9. Operation and } \\
\text { management of urban } \\
\text { freight transport systems. }\end{array}$ \\
\hline
\end{tabular}


End of Table 7

\begin{tabular}{|c|c|c|c|c|}
\hline $\begin{array}{l}\text { Thematic } \\
\text { area }\end{array}$ & Topic & Gap I & Educational requirement & Educational areas \\
\hline \multirow{2}{*}{ 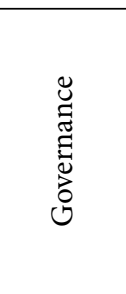 } & \multirow[t]{2}{*}{$\begin{array}{l}\text { Opera- } \\
\text { tion }\end{array}$} & $\begin{array}{l}\text { Limited coordination } \\
\text { among modes and } \\
\text { operators. }\end{array}$ & $\begin{array}{l}\text { Incorporation of transport operations } \\
\text { education and training materials that will focus } \\
\text { on multimodal systems. }\end{array}$ & $\begin{array}{l}\text { 10. Multimodal transport } \\
\text { optimization for } \\
\text { passenger transport. }\end{array}$ \\
\hline & & & $\begin{array}{l}\text { Development of education material on } \\
\text { integrated coordination and operation of } \\
\text { mega infrastructure facilities with special } \\
\text { reference to interchanges and the utilization of } \\
\text { technological advances. }\end{array}$ & $\begin{array}{l}\text { 11. Multimodal transport } \\
\text { optimization for freight } \\
\text { transport. }\end{array}$ \\
\hline \multirow{6}{*}{ 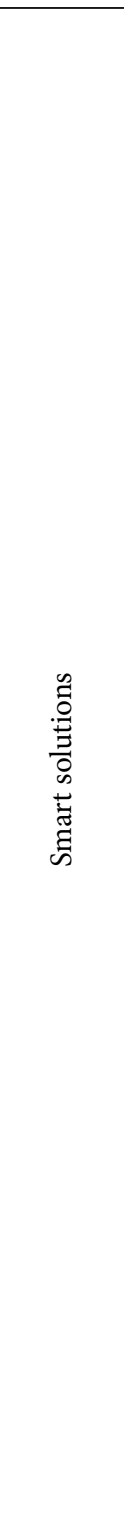 } & $\begin{array}{l}\text { Infor- } \\
\text { mation }\end{array}$ & $\begin{array}{l}\text { Limited multimodal } \\
\text { information. }\end{array}$ & $\begin{array}{l}\text { Exploration and utilization of technologies to } \\
\text { respond to transport information based needs. }\end{array}$ & $\begin{array}{l}\text { 12. Information systems for } \\
\text { passenger intermodal } \\
\text { terminals }\end{array}$ \\
\hline & Services & $\begin{array}{l}\text { Limited integrating } \\
\text { ticketing. } \\
\text { Existing services do not } \\
\text { offer travelers real-time } \\
\text { information across all } \\
\text { stages of a multimodal } \\
\text { trip } \\
\text { Possible conflicts } \\
\text { between vehicles and } \\
\text { pedestrians. } \\
\text { Not sufficient security } \\
\text { level. }\end{array}$ & $\begin{array}{l}\text { Development of course that integrates public } \\
\text { transport with smart solutions (technology and } \\
\text { policy oriented) and potential sustainability } \\
\text { impacts. } \\
\text { Incorporation in the program topics with } \\
\text { interchange and terminal design and planning } \\
\text { with reference to their special characteristics } \\
\text { and safety issues. }\end{array}$ & $\begin{array}{l}\text { 13. Integrated ticketing and } \\
\text { time table coordination. } \\
\text { 14. Design and safety } \\
\text { principles of transport } \\
\text { terminal infrastructure. }\end{array}$ \\
\hline & $\begin{array}{l}\text { Physical } \\
\text { proper- } \\
\text { ties }\end{array}$ & $\begin{array}{l}\text { Limited access for all. } \\
\text { Insufficient cycling and } \\
\text { walking facilities. } \\
\text { Environmental concerns } \\
\text { vary depending on } \\
\text { facilities' age. }\end{array}$ & $\begin{array}{l}\text { Development of education materials on } \\
\text { transportation planning and design of } \\
\text { intermodal terminals for all users to satisfy user } \\
\text { needs and fulfill sustainability principles. }\end{array}$ & $\begin{array}{l}\text { 15. Passenger terminal } \\
\text { design. }\end{array}$ \\
\hline & \begin{tabular}{|l|} 
New \\
consoli- \\
dation/ \\
distribu- \\
tion and \\
logistics \\
coop- \\
erative \\
concepts
\end{tabular} & $\begin{array}{l}\text { Individually planned } \\
\text { urban consolidation } \\
\text { centers. } \\
\text { Limited business and } \\
\text { transport operational } \\
\text { planning. }\end{array}$ & $\begin{array}{l}\text { Development training materials for case studies } \\
\text { of planning urban consolidation centers. }\end{array}$ & $\begin{array}{l}\text { 16. Urban freight terminals } \\
\text { design. }\end{array}$ \\
\hline & $\begin{array}{l}\text { Infor- } \\
\text { mation } \\
\text { technol- } \\
\text { ogies }\end{array}$ & $\begin{array}{l}\text { Limited cooperation } \\
\text { between publicly owned } \\
\text { and operated Intelligent } \\
\text { Transport Systems } \\
\text { and enterprise-level } \\
\text { software for supply- } \\
\text { chain management, } \\
\text { trip planning and fleet } \\
\text { management. }\end{array}$ & $\begin{array}{l}\text { Study of ITS characteristics and utilization } \\
\text { in case studies for the effective supply chain } \\
\text { management and trip planning. }\end{array}$ & $\begin{array}{l}\text { 17. Information technologies } \\
\text { for intermodal freight } \\
\text { transport. }\end{array}$ \\
\hline & $\begin{array}{l}\text { Smart } \\
\text { tran- } \\
\text { ship- } \\
\text { ment }\end{array}$ & $\begin{array}{l}\text { Limited use of } \\
\text { alternative, friendly to } \\
\text { environment and energy } \\
\text { technologies. }\end{array}$ & $\begin{array}{l}\text { Review of policies related to alternative fuels } \\
\text { and propulsion technologies, and estimation } \\
\text { of environmental impacts for intermodal } \\
\text { terminals. }\end{array}$ & $\begin{array}{l}\text { 18. Smart transhipment and } \\
\text { alternative transport } \\
\text { fuels. }\end{array}$ \\
\hline \multirow[t]{2}{*}{ 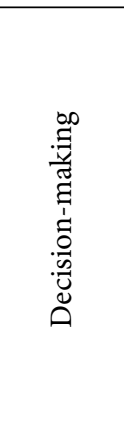 } & $\begin{array}{l}\text { Inter- } \\
\text { change } \\
\text { status } \\
\text { assess- } \\
\text { ment } \\
\text { and } \\
\text { users' } \\
\text { feedback }\end{array}$ & $\begin{array}{l}\text { Not obligatory. } \\
\text { Insufficient information } \\
\text { for decision-making: } \\
\text { only few surveys, data } \\
\text { not reliable; no network } \\
\text { assessment at the } \\
\text { strategic level, etc. } \\
\text { Limited data sharing. }\end{array}$ & $\begin{array}{l}\text { Development of integrated course material that } \\
\text { will focus on assessment practices with focus } \\
\text { on interchanges and life cycle impacts (society, } \\
\text { environment and economy) by including users' } \\
\text { satisfaction. }\end{array}$ & $\begin{array}{l}\text { 19. Risk assessment } \\
\text { analysis, behavioural } \\
\text { modelling, social cost } \\
\text { benefit analysis and } \\
\text { multi-stakeholder multi- } \\
\text { criteria assessment. }\end{array}$ \\
\hline & $\begin{array}{l}\text { Deci- } \\
\text { sion- } \\
\text { support } \\
\text { methods }\end{array}$ & Limited sharing of data. & $\begin{array}{l}\text { Incorporation of novel data collection methods } \\
\text { and exploitation of big data opportunities } \\
\text { in decision-making and analytics of freight } \\
\text { transport. }\end{array}$ & $\begin{array}{l}\text { 20. Innovative data } \\
\text { collection methods } \\
\text { to support decision- } \\
\text { making. }\end{array}$ \\
\hline
\end{tabular}

Note: grey cells are freight based. 
To this end, the recommendations for the curriculum of developed courses that will cover the interconnecting transport networks are formulated as follows:

1. Governance and policy development. The courses that are included in this thematic area will cover:

- issues related to the interconnection of transport with land use planning, legislative, institutional and organizational frameworks;

- the legal, organizational and institutional framework that applies in European Union countries, with emphasis on good practices;

- regional development and transportation planning tools for predicting demand for travel and transport;

- the methodologies, criteria and indicators determining the selection of site location for passenger and/or freight city hub establishment, as well as the factors boosting their development;

- the types of stakeholders involved (internal) or attached (external) in the city hub's establishment, development and operation and their roles, duties and jurisdiction.

2. Smart solutions. The courses that are included in this thematic area will cover:

- technological advancements and other innovative measures and tools, which enable the efficient operation of intermodal terminals, and provide high quality service and environmental and energy protection and sustainability;

- the detailed description of the methods, frameworks, measures and actions concerning smart solutions for the enhancement of operation and the upgrading of the provided level of service in intermodal terminals/city hubs.

3. Decision-making. The courses that are included in this thematic area will cover:

- the tools and methods, which feed the decision-making;

- traffic simulation and environmental impact assessment models, risk analysis tools, lifecycle analysis models and economic analysis methods;

- evaluation methods based on multi-stakeholder multi-criteria decision-making, sustainable business and organizational models for collaborative schemes amongst the stakeholders of the intermodal transport at chain;

- applications and management of smart solutions in intermodal terminals.

\subsection{Transport Courses}

Following Gap analysis II, the requirements per thematic area are linked with educational areas and transport courses:

1. Identification of educational areas. Based on the identified educational requirements for Latvia and the region, 20 educational areas were created for passenger and freight transport interchanges given the existing research, educational and training programs offered at research and educational institutes at European Union level.

2. Conversion to courses. The 20 educational areas that are identified in Step 1 are combined based on their content (where applicable) to shape 12 courses for passenger and freight transport interchanges. These 12 courses are going to be used for training and education in Latvia. These are grouped in thematic areas as follows:

- Governance: C1 - the European policy on intermodal transport, $\mathrm{C} 2$ - building business models for intermodal transport interchanges, C3 - sustainable development and transportation planning, $\mathrm{C} 4$ - operation and management of intermodal transport systems, and C5 - optimization of intermodal transport systems.

- Smart Solutions: C6 - intelligent services for passenger transportation, C7 - information systems for intermodal freight transport, C8 design of passenger transport interchanges, C9 - design of freight transport interchanges, and C10 - smart technologies for efficient logistics.

- Decision-making: C11 - decision-making methodologies, and C12 - data collection methods.

\section{Discussion}

The creation of a continuous European transport network without restrictions or barriers to access becomes one of the principal objectives of transport policy in $\mathrm{Eu}$ rope. Transport is being acknowledged as an important human activity that will require extensive professional and academic training and disciplinary research. While training and education is objectively at the meetingpoint between researches, technological and organizational systems, major features of transport sector need to be considered towards the development of a transport program that focus on intermodal transport terminals. These include the: (1) global character of transport as a subject of studies, (2) creation of a continuous transport service in Europe, (3) alliance of information and telecommunication technologies with transport, and (4) formation of new technological directions - intelligent transport systems.

The first level gap analysis that was performed between the interconnecting networks in European Union and the Latvia and the region showed that Latvia and the region cover most of the thematic areas in terms of practices for both passenger and freight interchanges, however, correspond adequately to basic needs and requirements. Regarding the passenger interchanges, the identified gaps impose in terms of governance and development a faster harmonization with European Union legal framework on interchanges and promotion of operational integration to improve coordination among modes and operators. Regarding the area of smart solutions it was noted a rather limited integration of technological and policy solutions in the transport system, which is complemented by the need of improving, in- 
terchange design to accommodate the needs of all users. Although freight interchange policy challenges were found to be similar to passenger interchanges, other identified gaps for freight based interchanges focus to ownership, management and operation of interchanges in Latvia and the region that require the enhancement of administrative and cooperative schemes between public and private sector as well as the development of business models. Regarding smart solutions, the individually planned urban consolidation centers, the limited business, and transport operation planning led to the need to develop a more rational strategic plan of urban consolidation/distribution centers by considering the market demand.

The second level gap analysis used as input the results from the first level gap analysis and data for existing educational, research and training programs in Latvia and the region to convert practice related requirements into educational gaps and requirements. On balance, the analysis showed that existing research, educational and training programs in transport in Latvia and the region present an adequate coverage of traditional transport principles and the generic methods that are used in transport for planning and design. However, these courses present several deficiencies that mostly focus on courses that are not specialized on specific transport modes and intermodality. Additionally, the environmental courses appear to be scarce for covering transportation planning and design in accordance to European Union laws and legislation. Based on the analysis, the transport courses that cover 'Smart solutions' (20\%) in Latvia and region are lower relative to the other two thematic areas of (1) 'Governance and policy development' (55\%), and (2) 'Decision-making' (56\%), which highlights the need for developing well integrated transport courses that mix smart solutions with the other two thematic areas for interconnecting networks. Smart solutions based courses should benefit by the development of courses that integrate public transport with smart solutions, and interchange and terminal design with accessibility and sustainability impacts.

The new transport developments for Latvia highlight the need for integrated planning and management to provide viable infrastructural intermodal terminals. These include: (1) ports that aim to promote the performance of business activities, (2) the railway network that aims to serve ports and connect Latvia and the region with European Union transport corridors, and (3) the Riga International Airport that aims to improve the environmental conditions. More specifically, the integration of the transport infrastructure with the trans-European system requires the development of coast shipping and combined transport. In addition, the enhancement of regional mobility requires the connection of secondary and tertiary nodes to TEN-T infrastructure, and the increase in the carrying capacity of main national motor roads requires the rehabilitation of the pavement.

The shift of transport sector in the Latvia and the region from road based transport to multimodal-based transport and the forthcoming 'Rail Baltica' project - a high quality rail connection - that will connect Baltic States and the centers of Western Europe highlight the necessity to assess existing transport programs and amend them based on Latvia's transport development.

\section{Conclusions}

As managerial and regulatory barriers restrict the incorporation of technological instruments and solutions to the sustainable dimension of decision-making and planning, this paper has sought to bridge this gap by organizing an educational and training program, which involves the participation of today's and tomorrow's researchers, decision-makers and practitioners. Based on the national priority of Latvia 'Growth of the national economy' and given the projected infrastructural developments for Latvia and region, the topic focused on intermodal interconnections, through analysis of data collection on interchanges for passenger mobility and freight transport, and educational and training transport programs.

Towards this direction, a methodology was developed that identifies existing gaps between the transport industry and the research, education and training programs and converts potential requirements into training courses. The 2-level gap analysis that was developed and implemented with respect to the thematic areas of (1) 'Governance and policy development', (2) 'Smart solutions', and (3) 'Decision-making', and the validation process that followed, has revealed several requirements that exist currently for passenger and freight interchanges and educational programs for Latvia and the region. The first level gap analysis that was performed between the interconnecting networks in European Union and the Latvia and the region showed that Latvia and the region cover most of the thematic areas in terms of practices for both passenger and freight interchanges. However, compared to European Union practice it performs poorer mainly due to limited incorporation of sustainability principles into planning and operation of terminals and limited integration of technological advances with new transport trends as well as business and management plans. The second level gap analysis showed that although several transport related programs in Latvia and region offer a wide variety of courses there is not a common integrated approach for the development of transport programs and transport courses content.

Based on revealed educational requirements, 12 transport related courses for passenger and freight transport interchanges have been designed. The courses will be integrated in a transport program that is scheduled to be addressed to students attending Master's and $\mathrm{PhD}$ courses in programs offered at the Transport and Telecommunication Institute in Latvia, on 'Transport Economics and Management', 'Transport and Logistics' and 'Telematics and Logistics'. Additionally, as a lifelong learning program it can be addressed to University graduates who practice their profession in the transport industry, thus work for an authority, Small and Mediumsized Enterprise, or other organization (Trans-logistics Educational forum). 
Concluding, the methodology developed in this paper for supporting the establishment of an educational program in transport interchanges may provide a significant background for the design and realization of future programs across regions. Transferring the findings of the current-state review in interconnecting transport networks and in research, educational and training programs at European level, and adapting the relevant findings at regional level, practitioners and universities' councils, can apply the proposed methodology and establish a coherent program in the topic of passenger and freight transport interchanges.

\section{References}

CCSC. 2012. National Development Plan of Latvia for 2014-2020. Cross-Sectoral Coordination Centre (CCSC) [Pārresoru koordinācijas centrs]. 71 p. Available from Internet: http://www.pkc.gov.lv/images/NAP2020\%20dokumenti/NDP2020_English_Final.pdf

CORDIS. 2016. Community, Research and Development Information Service. 2016. Available from Internet: http://cordis. europa.eu/home_en.html

EC. 2014. The role of Universities and Research Organisations as drivers for Smart Specialisation at Regional Level. European Commission. 54 p. Available from Internet: http:// ec.europa.eu/research/regions/pdf/publications/ExpertReport-Universities_and_Smart_Spec-WebPublication-A4. pdf

EC. 2009. Communication from the Commission to the European Parliament, the Council, the European Economic and Social Committee and the Committee of the Regions: Action Plan on Urban Mobility. Brussels, 30.9.2009. COM(2009) 490 final. 13 p. Available from Internet: http://eur-lex.europa.eu/LexUriServ/LexUriServ.do?uri=COM:2009:0490:F IN:EN:PDF

EC. 1999. REFORM: Research on Freight Platforms and Freight Organisation. European Commission. Directorate-General Transport. $131 \mathrm{p}$.

El Sawi, G. 1996. Curriculum Development Guide: Population Education for Non-Formal Education Programs of Out-ofSchool Rural Youth. Food and Agriculture Organization of the United Nations. Available from Internet: http://www. fao.org/docrep/009/ah650e/AH650E00.htm

Figliozzi, M. A. 2010. The impacts of congestion on commercial vehicle tour characteristics and costs, Transportation Research Part E: Logistics and Transportation Review 46(4): 496-506. http://doi.org/10.1016/j.tre.2009.04.005

Grimm, N. B.; Faeth, S. H.; Golubiewski, N. E.; Redman C. L.; Wu, J.; Bai, X.; Briggs, J. M. 2008. Global change and the ecology of cities, Science 319(5864):756-760. http://doi.org/10.1126/science.1150195

MDC. 2003. The Congruence Model: a Roadmap for Understanding Organizational Performance. Mercer Delta Consulting, LLC. 13 p. Available from Internet: http://ldt. stanford.edu/ gwarman/Files/Congruence_Model.pdf

Mineraud J.; Mazhelis, O.; Su, X.; Tarkoma, S. 2016. A gap analysis of internet-of-things platforms, Computer Communications 89-90: 5-16. http://doi.org/10.1016/j.comcom.2016.03.015

Nathanail, E.; Adamos, G.; Mitropoulos, L.; Yatskiv (Jackiva) I.; Kabashkin, I.; Savrasovs, M.; Malnaca, K.; Matzner, K. 2016. Good Practices of Research, Educational and Training Pro- grams on Smart Solutions for the Interconnection of Transportation Networks. ALLIANCE Deliverable D2.1. Project No 692426. Enhancing Excellence and Innovation Capacity in Sustainable Transport Interchanges. 164 p. Available from Internet: http://alliance-project.eu/wp-content/ uploads/2016/03/ALLIANCE_D2.1_GoodPractices.pdf Rouse, M. 2014. Gap Analysis. TechTarget, SearchCIO. Available from Internet: http://searchcio.techtarget.com/definition/gap-analysis

Russo, F.; Comi, A. 2012. City characteristics and urban goods movements: a way to environmental transportation system in a sustainable city, Procedia - Social and Behavioral Sciences 39: 61-73. http://doi.org/10.1016/j.sbspro.2012.03.091

Thomas, P. A.; Kern, D. E.; Hughes, M. T.; Chen, B. Y. 2015. Curriculum Development for Medical Education: a Six-Step Approach. 3rd edition. Johns Hopkins University Press. 312 p. 